\title{
GODORT Steering Committee
}

\section{Monday, June 26, 2017 1:00-2:30 pm, Palmer House, Clark 05}

\author{
Committee Chair: Sarah Erekson; Secretary: Laura Sare
}

\section{Welcome, Introductions}

Sarah Erekson welcomed everyone and asked for amendments to the agenda.

\section{Adoption of the Agenda}

Susanne Caro asked for an action item to be under the Task Forces section of the agenda for the Federal Documents Task Force. Andrea Sevetson moved to approve the agenda and David Utz seconded.

Approval of Minutes from 2017 Midwinter Conference Steering I and II, Steering Committee Conference calls and Steering reflector (posted to the wiki). Laura Sare moved to approve the minutes, Andrea seconded and the minutes were approved.

\section{Announcements}

Deadline for submission of meeting summaries for $D t t P$ 7/7/2017.

Deadline for submission of thank you letters (for event sponsors and committee/task force speakers) 7/21/2017.

Treasurer's Report-There is no update from the report since the Membership meeting. The question about the Freedom to Read Foundation will be taken care of after ALA.

GODORT Councilor report-Bill Sudduth said that today council Keith Michael Fields last day as executive director. Council passed the resolution on libraries as responsible spaces. The Committee on Organization changed the Website Advisory Committee to the Information Advisory Committee to broaden focus beyond website. The Policy Committee found an error in the policy. In 2000 wording was approved to ensure the executive director should have a Library Master's degree and this was never put in the policy. It was voted for but it was finally added to the policy manual. Bill was going to provide handouts for federal library advocacy-he will have them scanned and put online. For those going to the Hillary session, Bill gave an update on how to get to the room and go through security.

Jill suggested Counsel be told that when big people show up like Clinton members need to know when they are making their travel arrangements. Many people are missing Clinton because they can't change reservations. She also asked if meetings are recorded and where to find them. Steve explained that GODORT programs were recorded. Probably need to contact the sponsor of the program to ask if they can forward recordings on to you.

\section{Task Forces/Committees (Chairs)}

Andrea Morrison reported for Cataloging-Cataloging standards are changing and they want linked data categories like sponsoring or contracting bodies to be part of the standard. Also, there are no identifiers for Government Accession numbers. They need to get these in by April and to please send any concerns to them quickly so it can go through the bureaucracy.
Susanne Caro for Federal Documents Task Force (FDTF) moved to change the status of FDTF from a task force to an interest group, now Federal Information Interest Group (FIIG). This was approved by membership in yesterday's meeting. David seconded. FDTF Membership voted to send it to Steering.

Discussion-Shari wants to finish the reorganization and include how task forces are run. She hoped FDTF would wait to move forward until the State and International Task Forces had their needs met regarding moving to interest group status so they could all do it together, specifically the PPM implications of this change so that we can streamline everything for all the groups. Jill Long felt that all three groups do not have to be organized the same. Andrea also thought that once size does not fit all. David said we will have both Task Force and Interest group categories so the groups do not need to be all one or the other. Hallie liked Andrea's assessment that FIIG is a good pilot project and thought having an Interest Group would help with conference restructuring issue. Both Task Forces and (standing) Committees are dissolved by the GODORT Steering Committee, at the request of the membership of any particular group. In the case of both a Task Force, or a Committee, the members of the group vote to request Steering to dissolve them. The difference is that, while Committee members can vote to make this request, the entire membership of GODORT needs to vote for this action by Steering in the case of a Task Force, 
because all GODORT members constitute the membership of a particular Task Force.

Sarah called for a vote that had 2 no's 2 abstentions, the motion carried.

Vicki said that FIIG needs to come up with a new purpose for the next steering meeting.

International Documents Task Force had a virtual meeting before Annual. Kris Kasinovitz requested a thank you letter for those speakers.

Legislation-Hallie Pritchett reminded everyone about the motion to co-endorse with MAGIRT the USGS Libraries to the Washington office. The Legislative survey will go out on the wiki in the next week or so.

Andrea asked for someone to announce when $D t t P$ is published online. Robbie (Publications) said they are working on a solution for this.

Development-Andrea stated that in the next month or two she will provide a motion to send out a letter of solicitation of funds because email they tried was not successful.

\section{Old Business}

Membership voted to create a bylaws coordinator. Andrea moved to abolish the bylaws committee and David seconded, the motion carried.

Virtual meetings-Steering's goal was to implement virtual meetings with Adobe Connect. Sarah said it has been successful and available to all groups. Samantha Hagar is the coordinator and can help you.

Stephen Woods can be a backup but thinks that it needs to be more formal so Samantha can mentor someone to be backup and asked the Chair to send a message to get a volunteer backup. Rachel Dobkin was looking at cost assessment with Zoom and Stephen was going to work with Samantha to give a report to Steering about cost.

Rachel Dobkins wanted a discussion about how we archive and share information from virtual meetings. Sarah said that ALA Connect is making some changes and was going to ask for ALA to host a meeting to train us on the ALA Connect software (not GODORT's Adobe software). Stephen said that the Archivist needs to put our materials in ALA's repository.

\section{New Business}

Sarah talked about the Conference remodel-The goal was to make ALA annual more manageable and reduce campus size and put programs into subject tracts and increase sustainability.
Programs and discussion groups will be in the convention center. The biggest change is that there are going to be juried programs for those who want to do extra programming beyond the two we do get. Submissions have been opened and end in August for 2018 Annual. Sarah posted this to ALA Connect. We will need to make a decision about discussion groups soon if they want to have programs. Hallie said that virtual meetings have been successful and we can go that route as well. Simon asked if we could promote a "government information" stream in the new track system.

Shari had to take over Nominations and thanked David's help and all the other people who helped or volunteered to fill positions. Shari sent out a list. Shari moved to have a friendly amendment, her list was to have correct returning to voting on the appointments and that the list will be updated to correct a few problems. The motion carried to accept new memberships and appointments.

Hallie thanked Sarah for her leadership this year and thanks to Stephen Woods for his work too, and extended congratulations to Shari as new Chair.

Shari moved to adjourn, Vicki seconded. 